\title{
Response of Chickpea (Cicer aeritinum L.) Genotype to Intra and Inter Row Spacing at Huletegna Choroko, Southern Ethiopia
}

\author{
Tatek Tamiru ${ }^{1,}{ }^{*}$, Walelign Worku ${ }^{2}$, Worku Mengesha ${ }^{1}$, Getu Weyya ${ }^{3}$ \\ ${ }^{1}$ Department of Plant Science, Wolkite University, Wolkite, Ethiopia \\ ${ }^{2}$ School of Plant and Horticultural Science, Hawassa University College of Agriculture, Hawassa, Ethiopia \\ ${ }^{3}$ Department of Food Process Engineering, Wolkite University, Wolkite, Ethiopia
}

\section{Email address:}

tatektamiru2010@gmail.com (T. Tamiru),walelignworku@yahoo.com (W. Worku),worku.mengesha@wku.edu.et (W. Mengesha), getuweya@gmail.com (G. Weyya)

*Corresponding author

\section{To cite this article:}

Tatek Tamiru, Walelign Worku, Worku Mengesha, Getu Weyya. Response of Chickpea (Cicer aeritinum L.) Genotype to Intra and Inter Row Spacing at Huletegna Choroko, Southern Ethiopia. Ecology and Evolutionary Biology. Vol. 5, No. 4, 2020, pp. 148-158. doi: $10.11648 /$ j.eeb.20200504.15

Received: September 21, 2020; Accepted: October 6, 2020; Published: November 19, 2020

\begin{abstract}
Chickpea has a major role in the daily diet of the rural community and urban population as a good source of energy, protein, minerals, vitamins, fiber and its straw is used for animal feed, and it also improves soil fertility by fixing the atmospheric nitrogen. Optimum plant density and appropriate genotypes for a given agro ecology influences plant size, yield components and ultimately the seed yield. Hence, a field experiment was carried out to determine the effect of intra and interrow spacing on growth, yield and yield component of chickpea (Cicer aeritinum L.) Genotypes under rain fed condition in Huletegna Choroko, Southern Ethiopia in 2016 cropping season. A split-split plot design with three replications was used with two chickpea genotypes: Genotypes Habru and Mastewal were arranged in main plot and intra-row spacing of 5, 10 and $15 \mathrm{~cm}$ in sub-plot and inter-row spacing's of 30,40 and $50 \mathrm{~cm}$ in sub-sub plot. Days to flowering and hundred seed weight were significantly different between the two genotypes. Intra-row spacing had significantly affected physiological maturity, nodule dry weight plant ${ }^{-1}$, plant height, primary branch plant ${ }^{-1}$, pods plant $^{-1}$, seeds pod ${ }^{-1}$, above ground biomass and seed yield. Inter row spacing also significantly affected days to flowering, days to physiological maturity, nodule number plant ${ }^{-1}$, nodule dry weight, plant height, primary branch, pod plant ${ }^{-1}$, seed number $\operatorname{pod}^{-1}$, above ground dry matter and seed yield. Mastewal genotype obtained the maximum $\left(2.91 \mathrm{t} \mathrm{ha}^{-1}\right)$ grain yield at the combination of $15 \mathrm{~cm}$ intra row and $30 \mathrm{~cm}$ inter row spacing while Habru genotype obtained $\left(2.57 \mathrm{t} \mathrm{ha}^{-1}\right)$ at the same intra and inter-row spacing. Finally it could be concluded that intra row spacing of $15 \mathrm{~cm}$ and inter row spacing of $30 \mathrm{~cm}$ were found to be the optimum for maximum grain yield of chickpea using genotype Mastewal and Habru at Halaba, Huletegna choroko.
\end{abstract}

Keywords: Chickpea, Intra Row, Inter Row, Spacing, Split Split Plot, Genotypes

\section{Introduction}

In Ethiopia, chickpea is mainly grown in the central, northern and eastern highland areas of the country at an altitude of 1400-2300 m.a.s.1., where annual rainfall ranges between 700 and $2000 \mathrm{~mm}$ [5]. Chickpea, locally known as shimbra, is one of the major pulse crops (including faba bean, field pea, haricot bean, lentil and grass pea) and in terms of production, it is the second most important legume crop after faba beans [27].

The crop has a major role in the daily diet of the rural community and poor sectors of urban population and its straw is used for animal feed. Chickpea also fetch good price when sold in local market and hence generate cash to farmers. Moreover, the crop is being exported to Asia and Europe contributing positively to the country's foreign exchange earnings. The high nutritive value of chickpea can be judged by the fact that it 
contains $20 \%$ protein, $5 \%$ fats and $55 \%$ carbohydrates. Chickpea plays a significant role in improving soil fertility by fixing the atmospheric nitrogen and it meets up to $80 \%$ of its nitrogen $(\mathrm{N})$ requirement from symbiotic nitrogen fixation and can fix up to $140 \mathrm{~kg} \mathrm{~N} \mathrm{ha}^{-1}$ from air. Because of its deep tap root system, chickpea can withstand drought conditions by extracting water from deeper layers in the soil profile [19].

Even though chickpea has a number of uses, the productivity of the crop in Ethiopia under farmers condition is low $\left(1.73 \mathrm{t} \mathrm{ha}^{-1}\right)$ [14] as compared to its potential yield of the crop under improved management conditions $\left(3.5 \mathrm{t} \mathrm{ha}^{-1}\right)$. Access to inputs, low soil fertility and biotic constraints are the major factors currently limiting crop productivity in Ethiopia [33]. Also, constraints include low yield potential of landraces and their susceptibility to biotic and abiotic stresses, and poor cultural practices [26].

Plant density is one of the important characters, which can be manipulated to obtain the maximum production from per unit land area. The optimum plant density with proper geometry of planting depends on genotype, its growth habit and agro climatic conditions. The seed yield of chickpea is highly dependent on plant population [8]. Seed yield increases with increased plant density up to an optimum, which changes according to genotype. Plant density is very important to facilitate aeration and light penetration in to plant canopy for optimizing rate of photosynthesis [22]. Too high or too low plant densities can reduce grain yields as high densities use too much of the available soils nutrients early in the season and low densities do not fully exploit the available nutrients. Among the many yield limiting factors under farmers practice in Huletegna Choroko; plant population and selecting genotype are important. Due to lack of recommendations on inter and intra row spacing of chickpea genotypes at specific area, plant populations on farmers' fields appear lower or higher than the optimum. As a result very low yield is obtained. Hence, this study was initiated with the purpose of determining optimum planting density and spacing for chickpea production at Huletegna Choroko Southern Ethiopia.

The specific objectives of the study were to:

1) Assess the effect of inter and intra-row spacing on growth, yield and yield components of chickpea under rain fed condition at Huletegna choroko.

2) Evaluate the possible interaction of genotype in response to different inter and intra row spacing.

\section{Materials and Methods}

\subsection{Description of Study Area}

The experiment was conducted during the 2016 cropping season from August to December at farmer's field of Halaba special woreda, Huletegna Choroko in southern nation nationality people region (SNNPR). The kebele is located $315 \mathrm{~km}$ south west of Addis Ababa in the coordinates of $7^{0} 17^{\prime}$ $\mathrm{N}$ latitude and $38^{\circ} 06^{\prime} \mathrm{E}$ longitude with an altitude 1797 m.a.s.l. The average annual rainfall of the area over a decade was $952.5 \mathrm{~mm}$ with a range of 710.2 to $1177.9 \mathrm{~mm}$ while the annual temperature ranges from $13.2^{\circ} \mathrm{C}$ to $29.4^{\circ} \mathrm{C}$.

\subsection{Experimental Design and Treatments}

The experiment was laid out in split-split plot design with chickpea genotypes Habru and Mastewal in main plots, intrarow spacing of 5, 10 and $15 \mathrm{~cm}$ in sub-plots and inter-row spacing's of 30,40 and $50 \mathrm{~cm}$ in sub-sub plots, which have three replications. The sub sub-plot sizes were $3.6 \mathrm{~m} \mathrm{x} 3 \mathrm{~m}$ $\left(10.8 \mathrm{~m}^{2}\right)$. The total experimental area was $24 \mathrm{~m} \mathrm{x} 36.4 \mathrm{~m}$ $\left(873.6 \mathrm{~m}^{2}\right)$. The plot size was uniform for all treatments and the number of rows and number of plants per row were assigned based on the experimental treatments. All agronomic practices (fertilizer application, weeding, and etc.) were done equally for each plot.

\subsection{Agronomic Data Collection}

\subsubsection{Crop Phenology}

Days to flowering were determined as the number of days after seedling emergence to the period when $50 \%$ of the plants in a plot developed first flower. Days to maturity was taken as the number of days after seedling emergence to the period when $90 \%$ of the plants in a plot were ready for harvest as revealed by change in the foliage and pod colour and seed hardening in the pods.

\subsubsection{Growth and Nodulation}

Plant height was recorded at physiological maturity by measuring the main stem height from the ground up to the canopy height using a ruler from randomly selected five plants. Number of primary branches was counted from randomly selected five plants and the average for each treatment was recorded. Nodulation assessment was conducted at mid flowering stages. Five plants were selected from the second rows of left and right side and gently uprooted after it was excavated. The root was washed with tap water to remove the adhering soil and the number of nodules plant ${ }^{-1}$ was counted and the values averaged to give the number of nodules plant ${ }^{-1}$. In addition, the severed nodule from the roots, were oven dried at $70^{\circ} \mathrm{C}$ for 48 hours and their dry weight recorded to give nodule dry weight plant ${ }^{-1}$.

\subsubsection{Yield and Yield Components}

Data on number of pods plant ${ }^{-1}$ and seeds $\operatorname{pod}^{-1}$ were recorded from 5 randomly selected plants in each plot and average number plant ${ }^{-1}$ were recorded. The average number of seed per pod was recorded from 20 randomly selected pods taken from five randomly selected plants. The grain yield and above ground biomass was measured from three central rows. The harvested biomass were sun dried and thereafter its dry matter yield ha ${ }^{-1}, 100$ seed weight and grain yield $\mathrm{ha}^{-1}$, were measured using weighing balance and calculated on hectare basis.

\subsection{Statistical Analysis}

Results were evaluated by analysis of variance using the 
Statistical Analysis System (SAS 9.1) software [32] and mean separation was performed by Fisher's least significant difference (LSD) test when $\mathrm{F}$ test was significant at $\mathrm{P}<0.05$ [15].

\section{Results and Discussion}

\subsection{Days to Flowering}

There was significant difference between the two genotypes on days to flowering $(p<0.001)$. The mean value indicated that for days to flowering of chickpea genotype in this study ranged from 63 to 65 days (Table 1). Longer duration was observed in Habru (65 days) genotype and a shorter one was observed in Mastewal (63 days) genotype. This means that the duration of the time required for flowering of the genotype Mastewal was earlier in 1.72 days than genotype Habru. This might be attributed to the fact that days to flowering in chickpea are considered to be varietal characteristics, which is genetically controlled. Earlier studies showed that, the differential response to flowering among genotype was different. [45] reported differences among genotypes of chickpea in days to flowering. Intra-row spacing did not significantly influence days to flowering.

Inter-row spacing had significant $(\mathrm{p} \leq 0.001)$ effect on days to flowering. The lowest (64.00 days) and the highest (65.67 days) number of days to flowering was achieved at 30 and $50 \mathrm{~cm}$ inter-row spacing, respectively. This can be described by the fact that as inter-row spacing increases, number of days to flowering of chickpea was delayed since the vegetative growth of the wider spacing was vigorous and prolonged due to the absence of high competition for resource and no stress effect. The interaction effect of both two ways as well as three ways on days to flowering was non-significant.

Table 1. Effect of intra and inter-row spacing on phenology of chickpea genotype.

\begin{tabular}{lll}
\hline Treatments & Days to Flowering & Days to Maturity \\
\hline Genotype & & \\
Habru & $65.44 \mathrm{a}$ & 115.3 \\
Mastewal & $63.82 \mathrm{~b}$ & 113.6 \\
CV $(\%)$ & 2.01 & 1.48 \\
LSD $(\mathrm{p}<0.05)$ & 1.52 & $\mathrm{NS}$ \\
Intra-row spacing $(\mathrm{cm})$ & & \\
5 & 64.39 & $113.72 \mathrm{~b}$ \\
10 & 64.89 & $114.61 \mathrm{a}$ \\
15 & 64.61 & $115.10 \mathrm{a}$ \\
CV $(\%)$ & 1.36 & 0.94 \\
LSD $(\mathrm{p}<0.05)$ & $\mathrm{NS}$ & 0.82 \\
Inter-row spacing $(\mathrm{cm})$ & & \\
30 & $64.00 \mathrm{~b}$ & $113.61 \mathrm{~b}$ \\
40 & $64.22 \mathrm{~b}$ & $113.78 \mathrm{~b}$ \\
50 & $65.67 \mathrm{a}$ & $116.00 \mathrm{a}$ \\
CV & 1.4 & 0.9 \\
LSD & 0.64 & 0.73 \\
\hline
\end{tabular}

Means followed by the same letters in the same column are not significantly different from each other at 5\% level of significance, whereas the opposite is true for different letters.

\subsection{Days to Physiological Maturity}

Data collected for days to physiological maturity indicated that there were no significant differences between the genotypes. [45] reported that there was a difference among genotypes of chickpea in time to physiological maturity.

Intra-row spacing had a significant effect on days to physiological maturity. The lowest (113.72 days) and the highest (115.10 days) number of days to physiological maturity were recorded at 5 and $15 \mathrm{~cm}$ intra-row spacing, respectively. The hastened days to maturity in the case of narrower intra row spacing could be because of high competition for available resources in the soil, poor light interception in the canopy as compared to the wider intra row spacing as a result plants were enforced to complete its life cycle in the short period of time. This result was in accordance with [46] who reported a steady increase in the number of days to maturity of chickpea with increased intrarow spacing of $7.5,10$ and $15 \mathrm{~cm}$.

Days to physiological maturity was significantly ( $\mathrm{p} \leq$ 0.001 ) influenced by inter-row spacing. The time required for maturity of chickpea in the present study ranged from 113.61 - 116.00 days (Table 1$)$. The shortest (113.61 days) days to physiological maturity was achieved in $30 \mathrm{~cm}$ of inter-row spacing which is statistically similar with $40 \mathrm{~cm}$ inter-row spacing. The longer duration (116 days) of maturity for interrow spacing was obtained in $50 \mathrm{~cm}$ spacing. A steady increase in number of days to maturity took place with decreasing inter-row spacing (Table 1). These results are in agreement with [46] in chickpea. [18] also reported that decrease in days to physiological maturity by two days with increasing population density of chickpea from 20 to 50 plants $\mathrm{m}^{-2}$ on the Canadian prairies.

Table 2. Interaction effect of genotype and inter-row spacing on physiological maturity.

\begin{tabular}{lllll}
\hline \multirow{2}{*}{ Genotype } & \multicolumn{4}{l}{ Inter row spacing $(\mathbf{c m})$} \\
\cline { 2 - 5 } & $\mathbf{3 0}$ & $\mathbf{4 0}$ & $\mathbf{5 0}$ & Mean \\
\hline Habru & $115.11 \mathrm{ab}$ & $114.22 \mathrm{~b}$ & $116.55 \mathrm{a}$ & 115.29 \\
Mastewal & $112.11 \mathrm{c}$ & $113.33 \mathrm{bc}$ & $115.44 \mathrm{ab}$ & 113.63 \\
CV $(\%)=0.93$ & & & & \\
LSD $(\mathrm{P}<0.05)=1.67$ & & & & \\
\hline
\end{tabular}

Means followed by the same letters are not significantly different from each other at $5 \%$ level of significance.

\subsection{Plant Height}

The response of genotype to plant height was found to be non-significant $(\mathrm{P}<0.05)$. However, $[35,13,30]$ reported that significant differences among the genotypes of chickpea in plant height.

Plant height was significantly affected by intra-row spacing. Maximum plant height $(58.9 \mathrm{~cm})$ was recorded in 5 $\mathrm{cm}$ intra-row spacing, which was followed by $10 \mathrm{~cm}$ spacing $(53.8 \mathrm{~cm})$. The shortest plant height $(53.6 \mathrm{~cm})$ was recorded in $15 \mathrm{~cm}$ spacing, which is not significantly different to 10 $\mathrm{cm}$ intra-spacing. In this study, plant height was taller in higher plant population treatments and could be justified on 
the basis of increase in the number of plants per unit area causing high plant-to-plant competition for light, water and nutrient within row. In addition to this under close intra row spacing, the space for plant spreading was less and hence plant height increased significantly. Similar observations have been made by [24, 36] who observed plant height increase with high densities.

Effect of inter-row spacing on plant height was statistically found to be significant $(\mathrm{P}<0.05)$. Maximum plant height (58.9 $\mathrm{cm}$ ) was recorded in $30 \mathrm{~cm}$ spacing between rows, and followed by $40 \mathrm{~cm}$ spacing with $54.3 \mathrm{~cm}$ plant height while the lowest plant height $(53.2 \mathrm{~cm})$ was recorded in $50 \mathrm{~cm}$ spacing. The plant height was increased as the row spacing reduced (Table 3). With reducing row spacing the plant population per unit area was increased. Through increasing of plant density, the competition between plants for radiation interception is usually elevated which can lead to elongation of internodes. In line with this result [21] also stated that, high population in narrow row spacing for early maturing genotypes potentially increase plant growth, as they are able to utilize environmental factors more effectively. However, [31] had reported that nonsignificant effects of row spacing on plant height of chickpea. The effect of genotype and inter-row spacing interaction on plant height was found to be significant. The shortest plant height $(51.2 \mathrm{~cm})$ was obtained in Mastewal genotype planted at $50 \mathrm{~cm}$ spacing and the tallest plant $(59.31 \mathrm{~cm})$ was noticed at narrowest spacing of $30 \mathrm{~cm}$ (Figure 1). This result might be due to the fact that as the spacing among plants decreased the interplant competition for light increased while sparsely populated plants intercepted sufficient sunlight that enhanced the lateral growth.

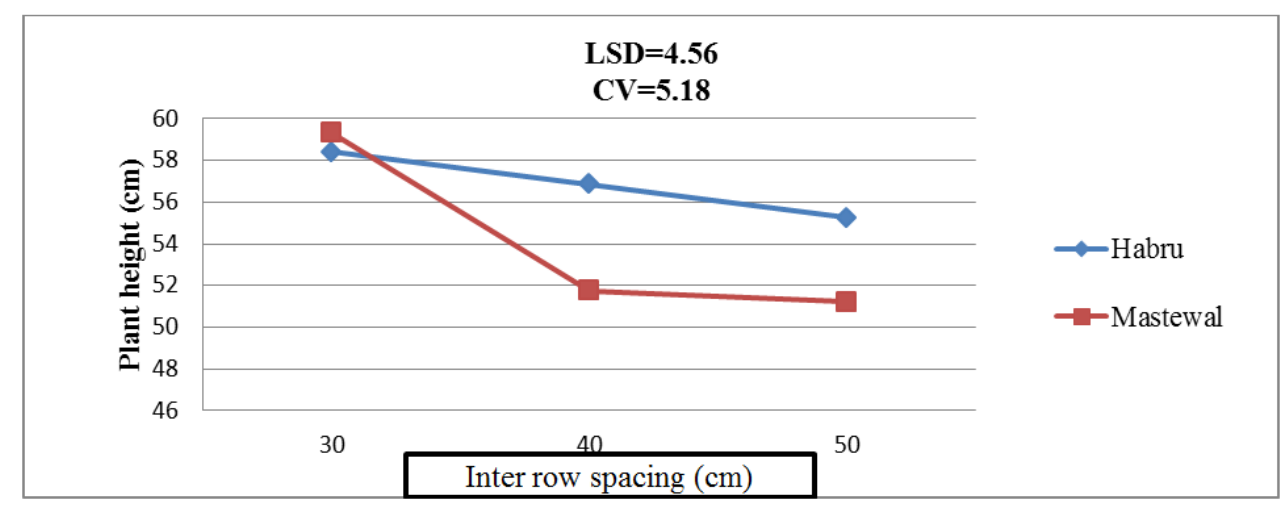

Figure 1. Interaction effect of genotype and inter-row spacing on plant height of chickpea.

\subsection{Number of Primary Branch Plant ${ }^{1}$}

Result on number of primary branch plant $^{-1}$ shows that there were no significant differences between genotypes. In line to this result [34] stated that the number of branches was not affected by genotype. Similarly, [4] also stated that there were no significant differences between genotypes for primary branch. In contrast with this, significant variations in number of primary and secondary branches plant ${ }^{-1}$ among the different genotypes of chickpea were reported by [3, 40].

The data in Table 3 revealed that intra-row spacing had significant $(p>0.001)$ effect on number of primary branches plant $^{-1}$. The number of branches plant ${ }^{-1}$ decreased with decreasing intra-row spacing. The treatments sown at $15 \mathrm{~cm}$ intra-row spacing produced the maximum branches (6.4) and it differed significantly from $5 \mathrm{~cm}$ and $10 \mathrm{~cm}$ intra-row spacing plant ${ }^{-1}$. The minimum number of branches plant ${ }^{-1}$ (4.4) was recorded from the treatments sown at the intra-row spacing of $5 \mathrm{~cm}$ (Table 3). The decrease in intra-row spacing resulted in more plants per unit area and hence less number of branches plant ${ }^{-1}$ due to more competition for nutrients, light, water and air. [36] Stated that the numbers of branches plant $^{-1}$ were significantly affected by different seed rates. [13] Obtained that primary branches increased when population density decreased in which the highest value, 2.75 branches plant $^{-1}$ was observed at the lowest population density which was 300,000 plants $\mathrm{ha}^{-1}$. The increment of branch number in this study was $12.73 \%$ as spacing changed from 5 to $15 \mathrm{~cm}$.

The result in (Table 3 ) indicated that inter-row spacing had a significant effect on number of primary branches plant $^{-1}$. The number of branches plant ${ }^{-1}$ increase with increase in inters row spacing. The plot sown at inter row-spacing of 50 $\mathrm{cm}$ produced the maximum branches (5.94) and did not differ statistically from $40 \mathrm{~cm}(5.33)$. The minimum number of branches plant ${ }^{-1}(4.83)$ was recorded from the plots sown at the inter-row spacing of $30 \mathrm{~cm}$, which was not significantly different from $40 \mathrm{~cm}$ inter-row spacing. The results showed that, wider spaced plants produced the greatest number of primary branches. As indicated earlier, wider spacing means less competition among plants for growth resources such as water, nutrients and solar radiation. This would mean more assimilates would be available to growth, and hence, greater allocation for more branching. This observation is in agreement with the report of [11] who indicated that plants in wider row spacing are capable of partitioning more resources to increase branch number in response to plant density. When inter-row spacing was shifted from $30 \mathrm{~cm}$ to $50 \mathrm{~cm}$ interrows, the average primary branch was increased by $6.89 \%$. [2] and [29] reported that reduction in the number of branches with increasing plant density is probably due to the intensified competition between adjacent plants and reduce light penetration into the plant canopy preventing growth of buds that making branches. 
Table 3. Effect of intra and inter-row spacing on growth and nodulation of chickpea genotype at Huletegna choroko.

\begin{tabular}{|c|c|c|c|c|}
\hline Treatments & Plant height(cm) & Number of $1^{0}$ branch plant ${ }^{-1}$ & Nodule number plant $^{-1}$ & Nodule dry weight plant ${ }^{-1}(\mathrm{~g})$ \\
\hline \multicolumn{5}{|l|}{ Genotype } \\
\hline Habru & 56.83 & 5.26 & 11.09 & 0.034835 \\
\hline Mastewal & 54.09 & 5.48 & 12.92 & 0.043364 \\
\hline CV (\%) & 5.15 & 15.82 & 22.44 & 24.53 \\
\hline LSD & NS & NS & NS & NS \\
\hline \multicolumn{5}{|c|}{ Intra-row spacing $(\mathrm{cm})$} \\
\hline 5 & $58.92 \mathrm{a}$ & $4.39 b$ & 10.83 & $0.024234 b$ \\
\hline 10 & $53.80 \mathrm{~b}$ & $5.28 \mathrm{~b}$ & 12.14 & $0.048756 \mathrm{a}$ \\
\hline 15 & $53.66 \mathrm{~b}$ & $6.44 a$ & 13.03 & $0.044308 \mathrm{a}$ \\
\hline CV (\%) & 7.89 & 24.89 & 23.19 & 18.08 \\
\hline LSD & 3.3663 & 1.0276 & NS & 0.0055 \\
\hline \multicolumn{5}{|c|}{ Inter-row spacing $(\mathrm{cm})$} \\
\hline 30 & $58.86 \mathrm{a}$ & $4.83 b$ & $13.63 \mathrm{a}$ & $0.0374 b$ \\
\hline 40 & $54.30 \mathrm{~b}$ & $5.33 \mathrm{ab}$ & $11.99 \mathrm{ab}$ & $0.0359 \mathrm{~b}$ \\
\hline 50 & $53.22 \mathrm{~b}$ & $5.94 \mathrm{a}$ & $10.39 b$ & $0.0448 \mathrm{a}$ \\
\hline CV (\%) & 5.17 & 21.28 & 21.19 & 13.14 \\
\hline LSD & 1.9746 & 0.7861 & 1.7496 & 0.0035 \\
\hline
\end{tabular}

Means followed by the same letters in the same column are not significantly different from each other at $5 \%$ level of significance, whereas the opposite is true for different letters.

\subsection{Nodule Number Plant ${ }^{1}$}

Nodule number plant ${ }^{-1}$ between chickpea genotype and among intra-row spacing was not significantly different. The average number of nodule number plant $^{-1}$ for intra-row spacing was increased as intra-row spacing increased from the narrower to the wider spacing, but there was no significant difference among them. Inter-row spacing had significant $(p<0.001)$ effect on mean nodule number plant $\left.^{-1}\right)$. The lowest number of nodule plant ${ }^{-1}$ (10.39) was obtained in $50 \mathrm{~cm}$ inter-row spacing and the highest (13.63) was obtained in $30 \mathrm{~cm}$ inter-row spacing (Table 3). Similarly, [48] found that the lowest number of nodule plant ${ }^{-1}(6.85)$ was observed from the highest population density $(30 \mathrm{~cm}$ inter row spacing) of chickpea crop. The interaction effects between genotype, intra-row and inter-row spacing on mean number of nodule per plant was non-significant

\subsection{Nodule Dry Weight Plant ${ }^{1}$}

Dry weight of nodule plant $^{-1}$ in chickpea was not significantly influenced by genotype. The Nodule dry weight was significantly influenced by intra-row spacing $(p,<0.001)$. The maximum value of nodule dry weight plant ${ }^{-1}$ for intrarow spacing was obtained at $10 \mathrm{~cm}(0.0488 \mathrm{~g})$ spacing which is at par with $15 \mathrm{~cm}(0.0443 \mathrm{~g})$ spacing. There were significant interaction effects among, genotype and intra-row spacing of chickpea crop). Mastewal genotype with $10 \mathrm{~cm}$ intra row spacing recorded maximum value $(0.056 \mathrm{~g})$ while Habru genotype with $5 \mathrm{~cm}$ spacing recorded the lowest $(0.0242 \mathrm{~g})$ nodule dry weight

Table 4. Interaction effect of genotype and intra-row spacing on nodule dry weight of chickpea.

\begin{tabular}{llll}
\hline \multirow{2}{*}{ Genotype } & \multicolumn{4}{l}{ Intra-row spacing (cm) } \\
\cline { 2 - 4 } & $\mathbf{5}$ & $\mathbf{1 0}$ & $\mathbf{1 5}$ \\
\hline Habru & $0.0242 \mathrm{c}$ & $0.0411 \mathrm{~b}$ & $0.0392 \mathrm{~b}$ \\
Mastewal & $0.0243 \mathrm{c}$ & $0.0564 \mathrm{a}$ & $0.0494 \mathrm{ab}$ \\
\hline
\end{tabular}

\begin{tabular}{|c|c|c|c|}
\hline \multirow{2}{*}{ Genotype } & \multicolumn{3}{|c|}{ Intra-row spacing (cm) } \\
\hline & 5 & 10 & 15 \\
\hline $\begin{array}{l}\text { CV }(\%)=18.09 \\
\mathrm{LSD}=0.0123\end{array}$ & & & \\
\hline
\end{tabular}

Means followed by the same letters are not significantly different from each other at $5 \%$ level of significance.

The response of nodule dry weight was significant to effects of inter-row spacing $(p<0.01)$. There were increments in nodule dry matter of chickpea with increase in inter-row spacing (Table 3 ). Higher nodule dry matter was recorded in plots with $50 \mathrm{~cm}(0.0469 \mathrm{~g})$ followed by $40 \mathrm{~cm}(0.0360 \mathrm{~g})$ while the minimum value was achieved at $30 \mathrm{~cm}(0.0366 \mathrm{~g})$ but it was not significantly different from $40 \mathrm{~cm}$ spacing (Table 3). Even though the number of nodules plant ${ }^{-1}$ were higher at narrower inter row spacing $(30 \mathrm{~cm})$ the dry weight was highest at wider spacing $(50 \mathrm{~cm})$ due to larger size of the nodule. There were highly significant interaction effects among intra and inter-row spacing on nodule dry weight of chickpea crop in this study). The maximum value of nodule dry weight was obtained in $10 \mathrm{~cm}$ intra row spacing with 30 $\mathrm{cm}$ inter row $(0.056 \mathrm{~g})$ while the minimum value was recorded in $5 \mathrm{~cm}$ intra row with $40 \mathrm{~cm}$ inter row spacing $(0.162 \mathrm{~g})$.

Table 5. Interaction effect of intra and inter-row spacing on nodule dry weight (gm) of chickpea genotype at Huletegna choroko.

\begin{tabular}{llll}
\hline \multirow{2}{*}{$\begin{array}{l}\text { Intra-row spacing } \\
(\mathbf{c m})\end{array}$} & \multicolumn{4}{l}{ Inter-row spacing $(\mathbf{c m})$} \\
\cline { 2 - 4 } & $\mathbf{3 0}$ & $\mathbf{4 0}$ & $\mathbf{5 0}$ \\
\hline 5 & $0.0204 \mathrm{~d}$ & $0.0162 \mathrm{~d}$ & $0.0361 \mathrm{c}$ \\
10 & $0.0558 \mathrm{a}$ & $0.0451 \mathrm{~b}$ & $0.0454 \mathrm{~b}$ \\
15 & $0.0359 \mathrm{c}$ & $0.0442 \mathrm{~b}$ & $0.0528 \mathrm{ab}$ \\
$\mathrm{CV}(\%)=13.14$ & & & \\
$\mathrm{LSD}=0.0074$ & & & \\
\hline
\end{tabular}

Means followed by the same letters are not significantly different from each other at $5 \%$ level of significance. 


\subsection{Number of Pods Plant ${ }^{1}$}

Statistical analysis did not show significant differences $(\mathrm{P}<0.05)$ between the two genotypes on number of pods plant $^{-1}$. There was a significant interaction effect of genotype with intra row spacing. The maximum value (59.56) of pod plant $^{-1}$ was obtained from Mastewal genotype in $15 \mathrm{~cm}$ intrarow spacing while the lowest pod plant ${ }^{-1}$ (33.00) was obtained in Mastewal genotype with $5 \mathrm{~cm}$ intra-row spacing of chickpea crop (Figure 2). This shows that different genotypes interact in different manner of intra-row spacing of chickpea crop. The wider intra-row spacing gave higher number of pods plant ${ }^{-1}$ possibly due to sufficient space where plants utilized more water, light, air and nutrients as a result, more photosynthetic activity.

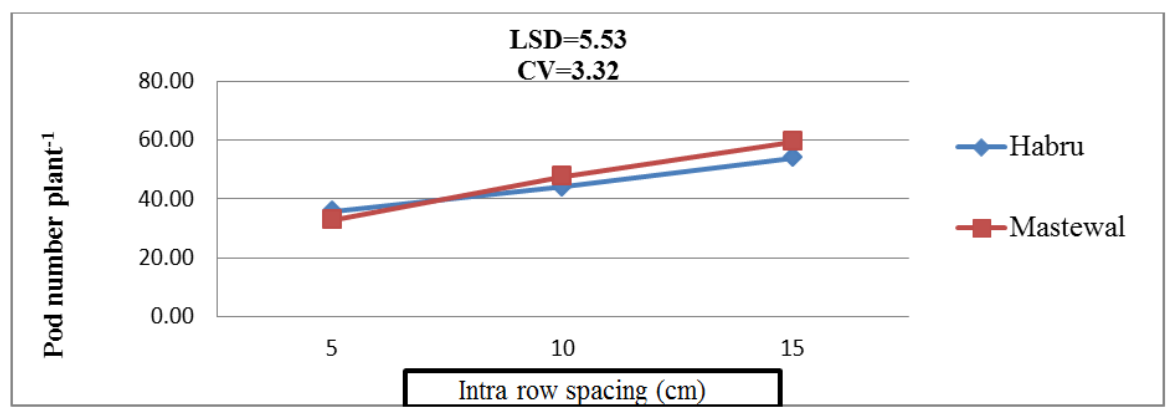

Figure 2. Interaction effect of chickpea genotype and intra-row spacing on pod number Plant ${ }^{-1}$.

Number of pods plant ${ }^{-1}$, an important primary yield component, was significantly $(\mathrm{p}<0.001)$ affected by different intra-row spacing. The results revealed that maximum number of pods plant $^{-1}$ (56.78) was obtained from $15 \mathrm{~cm}$ intra-row spacing which was followed by (45.89) of pods plant $^{-1}$ from intra-row spacing of $10 \mathrm{~cm}$ Whereas, minimum number of pods plant ${ }^{-1}$ (34.39) was obtained from $5 \mathrm{~cm}$ spacing. Higher number of pods plant ${ }^{-1}$ in $15 \mathrm{~cm}$ intra row spacing might be due to proper adjustment of plants in the field which facilitated more aeration, greater light interception and more photosynthetic activity on the other hand, in closer row spacing, the plant growth was decreased which resulted in less number of pods plant ${ }^{-1}$. It was observed that plants stem remained thin in densely populated plants and it might be due to congested plant population within plants which caused lodging to some degree and ultimately, reduce number of branch which can be reflected on number of pods plant ${ }^{-1}$. This finding is in agreement with that of [38] who reported decreased number of pods plant ${ }^{-1}$ with decreasing of intra row spacing on faba bean.

Effect of inter-row spacing on number of pods plant ${ }^{-1}$ was significantly different and average values ranged from 37.72 to 53. 56. highest average number of pods plant ${ }^{-1}$ (53.56) was noted in $50 \mathrm{~cm}$ inter-row spacing followed by $40 \mathrm{~cm}$ row spacing with 45.8 pods plant $^{-1}$, while the lowest number of pods plant $^{-1}$ (37.72) was recorded with $30 \mathrm{~cm}$ inter-row spacing). The increase in the number of pods plant ${ }^{-1}$ in wider row spacing may be due to vigorous plants as in wider spacing; plant grew vigorously and produced more branches which resulted in high number of pods plant ${ }^{-1}$. The reduction in number of pods plant ${ }^{-1}(29.57 \%)$ in narrower inter-row spacing might be due to higher number of plant per unit area where competition for nutrients, light, space and moisture was very tense as compared with the wider row spacing. Similarly, [28] stated that the number of pods plant ${ }^{-1}$ decreased with increasing plant density for chickpea. In case of dense population, the production of flower or pod presumably decreased because of competition for assimilates between the vegetative parts and the developing reproductive sink [25]. This part of yield components had the prominent role in legume on seed yield capacity [1]. There were significant interaction effects between intra and inter row spacing of chickpea on number of pod plant ${ }^{-1}$. The maximum number of pod plant ${ }^{-1}$ (65.50) was obtained in $15 \mathrm{~cm}$ intrarow with $50 \mathrm{~cm}$ inter-row spacing while the minimum value (27.5) was obtained in $5 \mathrm{~cm}$ intra-row and $30 \mathrm{~cm}$ inter-row spacing (Figure 3). The reduced competition for light and reduced overlapping from adjacent chickpea plants could have enabled the plants grown at wider spacing to utilize its energy for more branching and subsequently, the greater number of pods plant ${ }^{-1}$

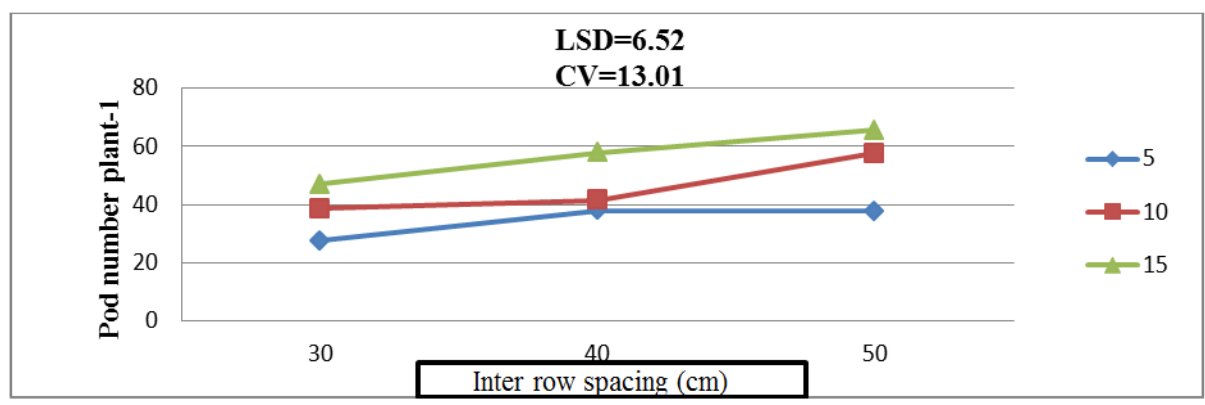

Figure 3. Interaction effect of intra and inter-row spacing on pod number plant ${ }^{-1}$. 


\subsection{Number of Seed Pod ${ }^{1}$}

As shown in table 6 the number of seed pod $^{-1}$ was not affected by chickpea genotype and intra-row spacing. In contrast with that of [42] who reported significant differences among genotype of chickpea on number of seeds pod $^{-1}$. [22] also reported significantly decreased number of seeds $\operatorname{pod}^{-1}$ as seed rate increased from $60 \mathrm{~kg} \mathrm{ha}^{-1}$ to $75 \mathrm{~kg} \mathrm{ha}^{-1}$ on chickpea.

Data reported in (table 6) show that there were significant differences among inter row spacing of chickpea on number of seed pod ${ }^{-1}$. The highest number of seed pod $^{-1}$ was obtained at $50 \mathrm{~cm}(1.53)$ and the lowest number was obtained at $40 \mathrm{~cm}$ (1.36) (Table 6). These results may suggest the competition between vegetative and reproductive structures of chickpea plants. In the lower densities, the rate of competition between plants is lower and the maximum potential of photosynthesis for distribution is available. Similarly, [41, 20] reported that with increasing density, due to increased competition, the number of seeds in the pod were reduced.

Table 6. Effect of inter and intra-row spacing on chickpea genotype on yield and yield components at Huletegna choroko in 2013.

\begin{tabular}{|c|c|c|c|c|c|}
\hline Treatments & Number of Pods plant ${ }^{-1}$ & Number of seed pod ${ }^{-1}$ & Grain yield $\left(\mathrm{t} \mathrm{ha}^{-1}\right)$ & Hundred seed weight (g) & Biomass dry weight(t ha $\left.{ }^{-1}\right)$ \\
\hline \multicolumn{6}{|l|}{ Genotype } \\
\hline Habru & 44.63 & 1.39 & 2.26 & $24.89 \mathrm{a}$ & 5.43 \\
\hline Mastewal & 46.74 & 1.49 & 2.40 & $22.06 b$ & 5.09 \\
\hline CV $(\%)$ & 7.79 & 12.91 & 9.87 & 3.43 & 12.79 \\
\hline $\operatorname{LSD}(0.05 \%)$ & NS & NS & NS & 0.9425 & NS \\
\hline \multicolumn{6}{|c|}{ Intra-row spacing (cm) } \\
\hline 5 & $34.39 \mathrm{c}$ & 1.42 & $2.01 \mathrm{c}$ & 23.05 & $6.05 \mathrm{a}$ \\
\hline 10 & $45.89 b$ & 1.46 & $2.58 \mathrm{a}$ & 23.13 & $4.71 b$ \\
\hline 15 & $56.78 \mathrm{a}$ & 1.43 & $2.39 \mathrm{~b}$ & 24.26 & $5.04 \mathrm{~b}$ \\
\hline CV $(\%)$ & 8.64 & 3.26 & 5.17 & 7.96 & 11.61 \\
\hline $\operatorname{LSD}(0.05 \%)$ & 3.03 & NS & 0.0925 & NS & 0.47 \\
\hline \multicolumn{6}{|c|}{ Inter-row spacing $(\mathrm{cm})$} \\
\hline 30 & $37.72 \mathrm{c}$ & $1.42 \mathrm{~b}$ & $2.74 a$ & 23.43 & $5.94 \mathrm{a}$ \\
\hline 40 & $45.78 b$ & $1.36 \mathrm{c}$ & $2.44 b$ & 23.22 & $5.05 \mathrm{~b}$ \\
\hline CV (\%) & 13.01 & 5.27 & 7.0033 & 4.92 & 13.66 \\
\hline $\operatorname{LSD}(0.05 \%)$ & 4.0894 & 0.0521 & 0.1123 & NS & 0.4948 \\
\hline
\end{tabular}

Means followed by the same letters in the same column are not significantly different from each other at 5\% level of significance, whereas the opposite is true for different letters.

\subsection{Hundred Seed Weight}

The data presented in table 6 showed that hundred seed weight was influenced significantly $(\mathrm{P}<0.001)$ by the chickpea genotype. The mean value of the genotype showed that genotype Habru had the higher (24.89 g) hundred seed weight than Mastewal (22.06 g). In line with this, [35] and [45] reported significant differences among genotypes of chickpea on hundred seed weight. [37] also reported that genotype had significant difference on hundred seed weight and the highest hundred seed weight was recorded for genotype Acos Dubie (63.53 g) whereas the lowest hundred seed weight was recorded for genotype Chefe (34.08 g).

Seed weight did not vary significantly among the intra-row spacing. These results are in line with the report of [47] and [43]. On the other hand, the findings of [23] showed that different plant densities influenced significantly the 1000 seed weight of chickpea.

Hundred seed weight was also not influenced significantly by inter-row spacing. [42] Reported that non-significant effect of inter-row spacing on hundred seed weight of chickpea. The interaction effects between inter, intra-row spacing and genotype were significant on hundred seed weight. The maximum value $(26.56 \mathrm{~g})$ was recorded in Habru genotype with $15 \mathrm{~cm}$ intra and $50 \mathrm{~cm}$ inter-row spacing while the minimum value $(20.28 \mathrm{~g})$ was recorded in Mastewal genotype with $5 \mathrm{~cm}$ intra-row and $30 \mathrm{~cm}$ inter-row spacing (Table 7). Lower number of plants per unit area at wider spacing had more nutrients availability and greater partition to seed as compared to closer spacing which resulted in more plump and bold seeds. Lowest density produced healthy individual seeds by receiving maximum sunlight for the process of photosynthesis.

Table 7. Interaction effect of genotype, intra and inter-row spacing on 100 seed weight $(\mathrm{g})$.

\begin{tabular}{lllll}
\hline \multirow{2}{*}{ Genotype } & Intra-row & \multicolumn{4}{l}{ Inter-row $(\mathbf{c m})$} \\
\cline { 2 - 5 } & $\mathbf{( c m )}$ & $\mathbf{3 0}$ & $\mathbf{4 0}$ & $\mathbf{5 0}$ \\
\hline \multirow{3}{*}{ Habru } & 5 & $25.66 \mathrm{ab}$ & $23.24 \mathrm{~b}$ & $23.77 \mathrm{~b}$ \\
& 10 & $24.78 \mathrm{ab}$ & $23.94 \mathrm{~b}$ & $25.00 \mathrm{ab}$ \\
& 15 & $25.35 \mathrm{ab}$ & $25.75 \mathrm{ab}$ & $26.56 \mathrm{a}$ \\
Mastewal & 5 & $20.28 \mathrm{c}$ & $21.69 \mathrm{bc}$ & $23.63 \mathrm{~b}$ \\
& 10 & $21.88 \mathrm{bc}$ & $21.68 \mathrm{bc}$ & $21.48 \mathrm{bc}$ \\
$\mathrm{CV}(\%)=4.92$ & 15 & $22.62 \mathrm{bc}$ & $22.97 \mathrm{bc}$ & $22.28 \mathrm{bc}$ \\
LSD $=2.3232$ & & & & \\
\hline
\end{tabular}

Means followed by the same letters are not significantly different from each other at $5 \%$ level of significance.

\subsection{Seed and Biological Yield}

Seed yield is ultimate outcome of various physiological, biochemical and phenological processes occurring in the plant 
system. The statistical analysis revealed that there was no significant difference between the two chickpea genotypes.

Data given in Table 6 showed that intra-row spacing significantly $(p<0.001)$ affected seed yield of chickpea. Maximum yield $\left(2.58 \mathrm{t} \mathrm{ha}^{-1}\right)$ was obtained in $10 \mathrm{~cm}$ spacing followed by $15 \mathrm{~cm}$ spacing $\left(2.4 \mathrm{t} \mathrm{ha}^{-1}\right)$. The minimum value $\left(2.01 \mathrm{t} \mathrm{ha}^{-1}\right)$ of seed yield $\mathrm{ha}^{-1}$ was obtained in $5 \mathrm{~cm}$ spacing. In case of low plant populations, some of the yield components might have increased on individual plant basis (number of pods plant ${ }^{-1}$ and biological yield) but would have decreased on per unit area basis. Hence, the lowest seed yield in $15 \mathrm{~cm}$ intra-row spacing might be due to relatively the inefficient utilization of available resources (light, space and nutrients) per unit area as compared to $10 \mathrm{~cm}$ intra-row spacing. In line with this, [12] justified that when soil moisture and nutrients are not limited, higher density is necessary to utilize other growth factors (solar radiation) efficiency of chickpea. The result also suggests that moderate intra-row spacing produced maximum grain yield, beyond that significant change in grain yield were observed. Therefore, seed yield of $10 \mathrm{~cm}$ spacing seems to be optimum which could be due to the most desirable population or planting density in the existing environmental conditions of Huletegna choroko.

The results table 6 showed that the effect of inter-row spacing on seed yield had highly significant differences $(\mathrm{P}<$ $0.001)$. The highest $\left(2.74\right.$ ton $\left.\mathrm{ha}^{-1}\right)$ and lowest seed yields $\left(1.81 \mathrm{t} \mathrm{ha}^{-1}\right)$ were obtained with the narrower $(30 \mathrm{~cm})$ and wider $(50 \mathrm{~cm})$ inter row spacing respectively (Table 6). This was mainly attributed to, at higher plant density; even though the individual plant performance was poor the grain yield was compensated with higher plant population. Therefore, the higher grain yields observed under higher plant population densities could be attributed to increased number of pods per unit area that resulted from higher number of branches per unit area. In a high plant population, competition between vegetative and reproductive organs arises which reduces the allocation of photosynthetic assimilates and resources to reproductive organs resulting in yield loss [17]. [10] reported that increasing plants population reduced yield of individual plants but increased yield per unit of area.

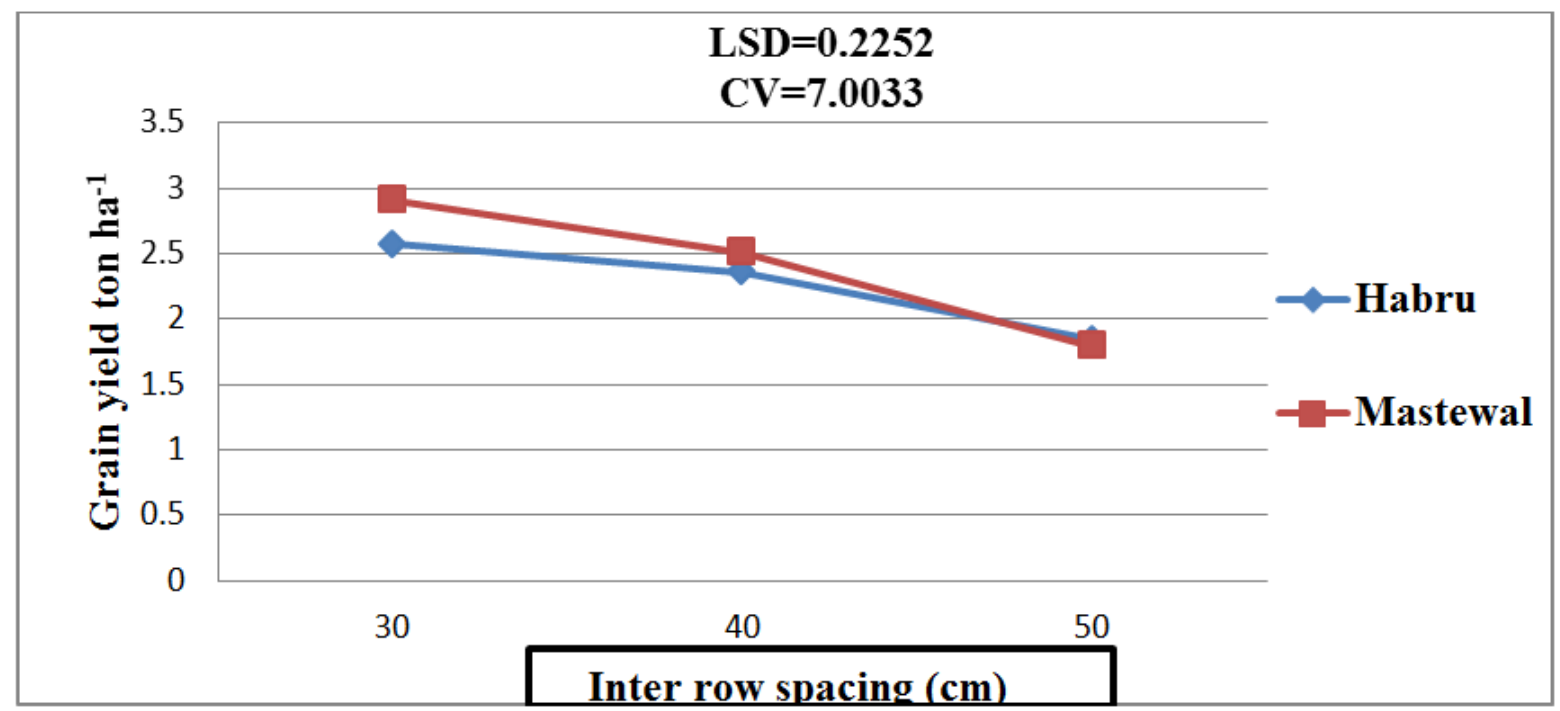

Figure 4. Interaction effect of genotype and inter-row spacing on grain yield in tha ${ }^{-1}$.

The interaction of inter row spacing with genotype was significant for grain yield. The maximum average grain yield $\left(2.91 \mathrm{t} \mathrm{ha}^{-1}\right)$ was recorded in $30 \mathrm{~cm}$ inter row spacing with Mastewal genotype followed by Habru at the same spacing. Grain yield declined with increasing inter row spacing for both genotypes (Figure 4). There was also significant interaction effects between intra and inter row spacing on grain yield of chickpea. Comparably greater yields were produced under both $10 \mathrm{~cm}$ and $15 \mathrm{~cm}$ intra row spacing combined with $30 \mathrm{~cm}$ inters row spacing (Figure 5). The higher seed yields noted in 15 and $10 \mathrm{~cm}$ intra row with 30 $\mathrm{cm}$ inter row spacing due to optimum number of plants per unit area which compensated the effect of decrease in other yield components like number of pods per plant, number of seeds per pod and hundred seed weight. These components though decreased on plant ${ }^{-1}$ basis, yet yield actually increased on per unit area basis. The plants grown with wider spacing had more area of land around them to draw the nutrition and had more solar radiation to absorb for better photosynthetic process and hence performed better at individual basis. The reason for deviation of this linearity in case of seed yield per unit area is that the yield does not entirely depend upon the performance of individual plant but also interact with the total number of plants per unit area and yield contributing parameters. [6] and [11] reported increased yield from higher plant populations are primarily the result of increased light interception during grain-filling by the crop canopy of soya bean. 


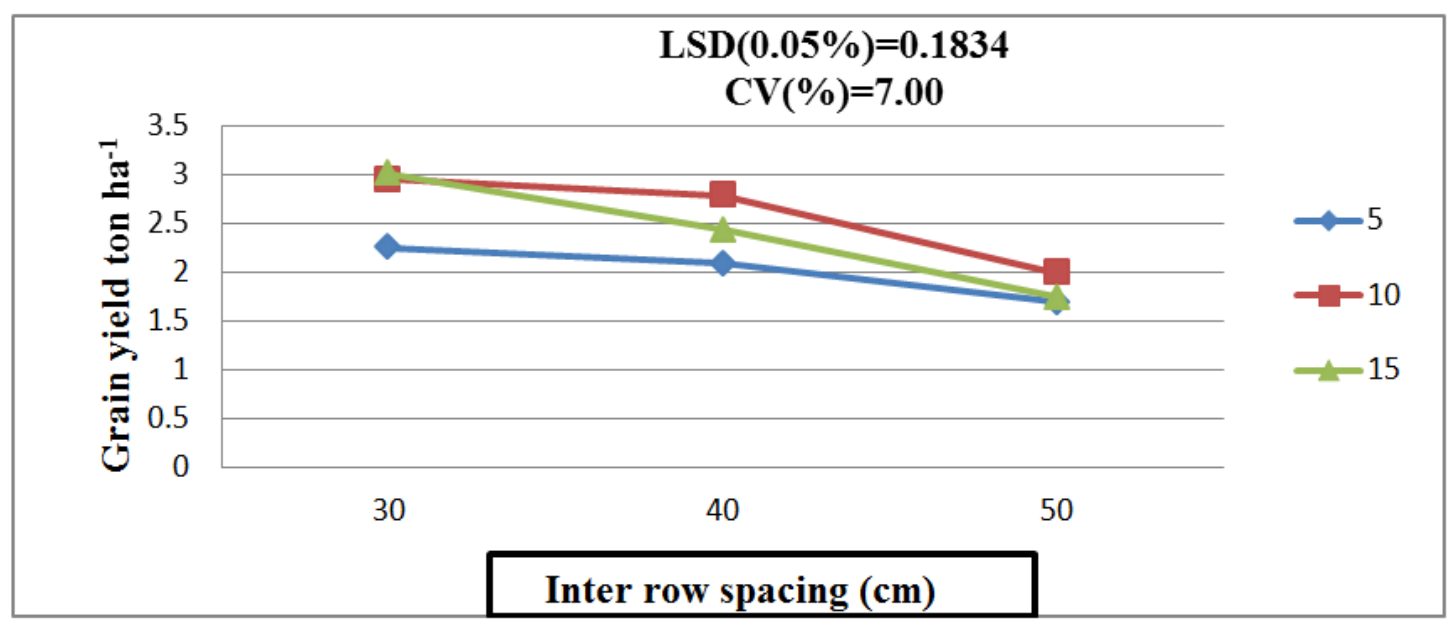

Figure 5. Interaction effect of intra row and inter-row spacing on grain yield in tha ${ }^{-1}$.

Biological yield is sum total of all dry matter produced through physiological and biochemical processes occurring in the plant system. There was no significant $(p<0.05)$ difference on above ground dry matter between genotypes In line with this, [35] reported statistically non-significant differences of the biological yield among genotype of chickpea.

Biological yield was significantly affected by intra-row spacing which ranged from 4.71 to $6.05 \mathrm{t} \mathrm{ha}^{-1}$ ). Maximum average biological yield of $\left(6.05 \mathrm{t} \mathrm{ha}^{-1}\right)$ was recorded in the treatments with $5 \mathrm{~cm}$ intra-row spacing and the lowest biological yield of $4.71 \mathrm{t} \mathrm{ha}^{-1}$ was recorded $10 \mathrm{~cm}$ intra-row spacing, which was at par with $15 \mathrm{~cm}$ intra-row spacing (Table 6). Although in most circumstance by increasing density biological yield has been raised under various environmental conditions, but in some cases, yield of individual plants is too low to be compensated with the density increment.

Inter-row spacing had significantly different effects $(\mathrm{P}<0.05)$ on above ground dry matter yield of chickpea. Maximum biological yield (5.94 $\left.\mathrm{t} \mathrm{ha}^{-1}\right)$ was recorded in 30 $\mathrm{cm}$ inter-row spacing followed by $40 \mathrm{~cm}$ inter-row spacing with a biological yield value of $5.05 \mathrm{t} \mathrm{ha}^{-1}$. The lowest biological yield of $4.81 \mathrm{t} \mathrm{ha}^{-1}$ was obtained at $50 \mathrm{~cm}$ interrow spacing, but it was not significantly different with $40 \mathrm{~cm}$ spacing. In case of low plant populations, some of the yield components might have increased on individual plant basis but would have decreased on per unit area basis. On contrary, in dense populations number of plants increased per unit area and yield components decreased on individual basis and eventually the total biological yield increased. These result were in line with [9] who planted chickpea at four different plant population densities $(5000,50,000,100,000$ and 200,000 plants/ha) and reported that dry matters (DM) accumulated over time were affected by plant population densities.

\section{Summary and Conclusion}

The result of the study showed the presence of significant differences between the two genotypes and inter-row spacing on days to flowering. Inter-row spacing had significant effect on number of nodule plant ${ }^{-1}$. Plant height was significantly affected by intra-row and inter-row spacing. The numbers of pods plant ${ }^{-1}$ and seed pod ${ }^{-1}$ were highly affected by intra-row and inter row spacing. Above ground dry matter was significantly affected by intra-row spacing which ranged from 4.71 to $6.05 \mathrm{t} \mathrm{ha}^{-1}$. Seed yield was not significantly affected by genotypes. However, intra and inter-row spacing had significantly affected seed yields.

The interaction of intra and inter-row spacing also had significant difference on grain yield. Greater yields were produced under both $10 \mathrm{~cm}\left(2.95 \mathrm{tha}^{-1}\right)$ and $15 \mathrm{~cm}\left(3.01 \mathrm{tha}^{-1}\right)$ intra row spacing combined with $30 \mathrm{~cm}$ inters row spacing. Even though, the yield of $10 \mathrm{~cm}$ and $15 \mathrm{~cm}$ intra row spacing had no significant difference $15 \mathrm{~cm}$ spacing was selected in order to reduce seed cost. The interaction of inter row spacing with genotype also had significant difference for grain yield. The maximum average grain yield $\left(2.91 \mathrm{t} \mathrm{ha}^{-1}\right)$ was recorded in $30 \mathrm{~cm}$ inter row spacing with Mastewal genotype followed by Habru $\left(2.57 \mathrm{t} \mathrm{ha}^{-1}\right)$ at the same inter row spacing. it can be conclude that Mastewal genotype obtained the maximum $\left(2.91 \mathrm{t} \mathrm{ha}^{-1}\right)$ grain yield at the combination of $15 \mathrm{~cm}$ intra row and $30 \mathrm{~cm}$ inter row spacing while Habru obtained $\left(2.57 \mathrm{t} \mathrm{ha}^{-1}\right)$ yield at the same intra and inter row spacing.

In conclusion, plant density had a significant influence on the phenology, growth, yield and yield components of chickpea genotype. From the above results, seed yield can be considerably enhanced by the use of $30 \mathrm{~cm}$ inter and $15 \mathrm{~cm}$ intra-row spacing for both (Mastewal and Habru) genotype at Halaba Huletegna choroko Southern Ethiopia.

\section{Acknowledgements}

Authors extend special thanks and appreciation to Canadian International Food Security Research Fund (CIFSRF) whose contribution for accomplishment of this work was very great. Deepest and respectful thanks to Atsede Shimelis for her love, encouragement and support. 


\section{References}

[1] Aghaalikhani M, Ghalavand A, Ala A. 2006. Effect of plant density on yield and yield components of two cultivars and a line of mungbean (Vigna radiate L.) Wilczek in Karaj region. Journal of Sciences and Technology of Agriculture and Natural Resources. Water and Soil Science 9 (4), 111-121.

[2] Akhtar, M. S., Siddiqui, Z. A., 2008. Effects of Glomus fasciculatum and Rhizobium sp. on the growth and root-rot disease complex of chickpea. Archives of Phytopathology and Plant Protection 40, 37-43.

[3] Ali, M., Nawab, G., Rasool and M. Saleem, M., 2008. Estimates of Variability and Correlations for Quantitative Traits in Cicer arietinum. Journal of Agriculture and Social Sciences, 4: 177-79.

[4] Alihan Cokkizgin, 2012. Botanical characteristics of chickpea genotypes (Cicer arietinum L.) under different plant densities in organic farming. Scientific Research and Essays, 7 (4): 498503.

[5] Anbessa, Y., and Bejiga G. 2002. Evaluation of Ethiopian chickpea landraces for tolerance to drought. Genetic Resources and Crop Evolution 49 (6): 557-564.

[6] Andrade FH., Calviño P., Cirilo A. and Barbieri P. 2002. Yield responses to narrow rows depend on increased radiation interception. Agronomy Jounal. 94: 975-980.

[7] Ayaz, S.; Mckenzie, B. A. and Hill G. D. (1999). The effect of plant population on dry matter accumulation, yield and yield components of four grains legumes. Agronomy New Zealand 29: 9-15.

[8] Ayaz, S. B., A. Mckenzie., B. A. Hill and D. L. Mcneil (2000). The effect of plant population on dry matter accumulation, yield and yield components of four grain legumes. New Zealand, Journal of Agronomy 29: 9-15.

[9] Ball, R. A., L. C. Purcell and E. D. Vories. 2000. Short-season soybean yield compensation in response to population and water regime. Crop Science, 40: 1070-1078.

[10] Caliskan S., Aslan M., Uremis I. and Caliskan ME. 2007. The effect of row spacing on yield and yield components of full season and doublecropped soybean. Turky Journal of Agriculture and Forestry. 31: 147-154.

[11] Chandrasekaran, B., K. Annadurai and E. Somasundaram, 2010. A Textbook of Agronomy. Published by New Age International (P) Ltd. Publishers, New Delhi, India.

[12] Cokkizgin, A., 2012. Botanical Characteristics of Chickpea Genotypes (Cicer arietinum L.) Under Different Plant Densities in Organic Farming. Scientific Research and Essays. Academic Journal, 7 (4): 498-503. Available online at http://www.academicjournals.org/SRE.

[13] CSA (Central Statistical Agency), 2012. Agricultural sample survey. Report on land Utilization, Statistical Bulletin 302. Addis Ababa, Ethiopia: Central Statistics Authority.

[14] Duzgunes O, Kesici T, Gurbuz F (1987). Statistical Methods I. Ankara University, Agricultural Engineering Faculty Press: 861, pp. 229.

[15] Fallah S. 2008. Effects of Planting Date and Density on Yield and its Components in Chickpea (Cicer arientinum L.) Genotypes under Dryland Conditions of Khorram-Abad. Journal of Science and Technology of Agriculture and Natural Resources 45, 123-135, http://jstnar.iut.ac.ir/browse.php? a_code $=A-10-2-902$.

[16] Gan, Y. T., R. R. Miller, B. G. Mc Conkey, R. R. Zentner, P. H. Liu and C. L. Mc Donald, 2003. Optimum Plant Population Density for Chickpea and Dry Pea in a Semiarid Environment. Canadian Journal of Plant Science, 83 (1): 1-9.

[17] Gaur, PM, S. Tripathi, CLL. Gowda, GV. Ranga Rao, HC. Sharma, S. Pande and M. Sharma, 2010. Chickpea Seed Production Manual. ICRISAT, Andhra Pradesh, India. 28 pp.

[18] Hayat F, Arif M, Kakar KM. 2003. Effects of seed rates on mungbean varieties under dry land conditions. International Journal of Agriculture and Biology 5 (2), 160-161.

[19] James, A. T., R. J. Lawn and B. C. Imnie, (1996). Raising Soybean Yield through Application of Crop Physiology to Agronomy and Breeding. Dept. of Botany and Tropical Agriculture. J. Cook Univ. Australia Qld 4811.

[20] Khan, E. A., M. Aslam, H. K. Ahmad, M. Ayaz and A. Hussain. 2010. Effect of row spacing and seeding rates on growth yield and yield components of chickpea. Sarhad Journal of Agriculture, 26 (2): 201-211.

[21] Khan, M., M. A. Malik, M. F. Saleem, M. A. Cheema and A. Ahmad. 2000. Effect of different seeding times and seed rates on the growth yield and quality of ricebean. Int. J. Agric. \& Biol., 2 (1-2): 104-106.

[22] Khan, M. B. and M. Asif. 2001. Growth and yield response of mash bean genotypes to various planting densities. J. Res., (Science), 12 (2): 167-170.

[23] Khanna-Chopra, R. and S. K. Sinha. 1987. Chickpea: physiological aspects of growth and yield, p. 163-189. In: M. C. Saxena and K. B. Singh (eds.), The chickpea. CAB International, Wallingford, UK.

[24] Legesse Dadi, Senait Regassa, Asnake Fikre and Demissie Mitiku. 2005. Adoption of chickpea varieties in the central highlands of Ethiopia. Research Report 62. EARO (Ethiopian Agricultural research Organization), Addis Ababa, Ethiopia.

[25] Menale Kassie, Bekele Shiferaw, Solomon Asfaw, Tsedeke Abate, Geoffrey Muricho, Setotaw Ferede, Million Eshete, and Kebebew Assefa. 2009. Current Situation and Future outlooks of the Chickpea Sub sector in Ethiopia. International Crops Research Institute for the Semi Arid Tropics (ICRISAT), Nairobi, and Ethiopian Institute of Agricultural Research (EIAR), Deber Zeit Agricultral Research Centre, Debre Zeit, Ethiopia. pp 1-43.

[26] Momoh, E. J. and Zhou W., 2001. Growth and yield responses to plant density and stage of transplanting in winter oilseed rape (Brassica napus L). Journal of Agronomy and Crop Science, 186: 253-259.

[27] Rafiee M, Alinzhad A, Sakinzhad T. 2006. The effect of plant density on stem retransfer percent leaf chlorophyll rate, rate of transpiration on canopy and seed filling growth of chickpea cultivars in dry land. First Agro physiological farming plants congress.

[28] Rasul, F., M. A. Cheema, A. Sattar, M. F. Saleem and M. A. Wahid, 2012. Evaluating the Performance of Three Mungbean Varieties Grown under Varying Inter-row Spacing. Journal of Animal \& Plant Sciences, 22 (4): 1030-1035. 
[29] Sarwar MY (1998). Effect of different fertilizer doses and row spacing on growth and yield of gram (Cicer arietinum L.). MSc. Thesis, University of Agriculture, Faisalabad, Pakistan, pp. 76.

[30] SAS (2004). SAS/STAT 9.1. User's guide: Statistics. SAS institute Inc., Carry, NC, USA, p. 5121.

[31] Schneider, K. and L. Anderson, 2010. Yield Gap and Productivity Potential in Ethiopia Agriculture: Staple Grains and pulses. Evans school policy Analysis and Research (EPAR) of the Bill and Melinda Gates Foundation. Evans Schools of public Affairs, university of Washington. Brief No. 98.

[32] Shamsi K, Kobraee S, Rasekhi B (2011). The effects of different planting densities on seed yield and quantitative traits of rainfed chickpea (Cicer arietinum L.) varieties. Afr. $J$. Agric. Res., 6 (3): 655-659.

[33] Shamsi, K. and S. Kobraee. 2009. Effect of plant density on the growth, yield and yield components of three soybean varieties under climatic conditions of Kermanshah, Iran. Animal and Plant Sciences Journal, 2 (2): 96 - 99.

[34] Sharar MS, Ayub M, Nadeem MA, Noori SA. 2001. Effect of different row spacings and seeding densities on the growth and yield of gram (Cicer arietinum L.). Department of Agronomy, University of Agriculture, Faisalabad, Pakistan. Pakistan Journal of Agricultural Science, 38:51-53.

[35] Shiferaw M. 2013. Response of Kabuli Chickpea (Cicer Arietinum L.) Varieties to Plant Spacing At Debre Zeit, Central Ethiopia M.Sc. Thesis.

[36] Sileshi Sh. 2013. Response of Faba bean (vicia faba L.) To Application of Phosphorus and Inter and Intra-row spacing at Teticha, Southern Ethiopia M.Sc. Thesis, University of Hawassa, Hawassa College of Agriculture, Ethiopia. 24 pp.

[37] Syed, M. A., M. R. Islam, M. S. Hossain, M. M. Alam and M.
N. Amin, 2012. Genetic Divergence in Chickpea (Cicer arietinum L.). Bangladesh Journal of Agriculture Research, 37 (1): 129-136.

[38] Tawaha ARM, Turk MA, Lee KD. 2005. Adaptation of chickpea to cultural practices in Mediterranean type environment. Research Journal of Agriculture and Biological Sciences 1 (2), 152-157.

[39] Thangwana, N. M. and J. B. O. Ogola, 2012. Yield and Yield Components of Chickpea (Cicer arietinum): Response to Genotype and Planting Density in Summer and Winter Sowings. Journal of Food, Agriculture \& Environment, 10 (2): $710-715$.

[40] Tonçer, Ö and S. Kizil. 2004. Effect of seed rate on agronomic and technologic characters of Nigella sativa L. Int. J. Agric. \& Biol., 6 (3): 529-532.

[41] Tripathi, S., V. Sridhar, A. K Jukanti, K. Suresh, BV Rao, CLL Gowda and P. M. Gaur, 2012. Genetic Variability and Interrelationships of Phenological, Physicochemical and Cooking Quality Traits in Chickpea. ICRISAT, Patancheru, Hyderabad, Andhra Pradesh, India.

[42] Valimohammadi, F., M. Tajbakhsh and A. Saeid, 2007. Comparison of Winter and Spring Sown Dates and Effect of Plant Density on Yield Components and Some Quality, Morphological Traits of Chickpea (Cicer arietinum L.) under Environmental Conditions of Urmia, Iran. Journal of Agronomy, 6 (4): 571-575.

[43] Yilmaz, N. 2003. The effects of seed rate on yield and yield components of soybean (Glycine max L. Merill). Pak. J. Biol. Sci., 6 (4): 373-376.

[44] Yordanos Fekade. 2013. Effect of population density and weeding frequency on Growth and Yield of Chickpea (Cicer arietinium L.) at Meskan Woreda, Gurage Zone, Southern Ethiopia. MSc. Thesis University of Hawassa, Hawassa College of Agriculture, Ethiopia. 